\title{
Nuoret paikallisina vaikuttajina verkossa
}

Tämän päivän nuoret ovat eläneet mediayhteiskunnassa syntymästään lähtien, ja varsinkin informaatioteknologian osalta heitä pidetään nopeina omaksujina uuden teknologian käyttöönotossa (early adapters) yhdessä korkeasti koulutettujen ja hyvin toimeentulevien aikuisten kanssa. Nuoret on myös nähty mahdollisina uuden, poliittisen toiminnan ja edustuksellisen demokratian ulkopuolelle suuntautuvan osallistumiskulttuurin tienraivaajina. Voisiko siis tietoverkko olla paikka nuorten uudenlaiselle yhteiskunnalliselle osallistumiselle? Internetissä on julkaistu viimeisten viiden vuoden aikana varmaankin tuhansia juuri nuorille suunnattuja kansalaissivustoja eri puolilla maailmaa, enimmäkseen erilaisten nuorten kehitystä tukemaan pyrkivien järjestöjen ja muiden organisaatioiden toimesta. Suomessa paikallisia ja kansallisia nuorten kansalaissivustoja ovat ryhtyneet toteuttamaan nuorisotyön ja koulun toimijat sekä nuoret itse. Näiden projektien merkityksestä nuorten valtautumiselle ei vielä kovin paljon ole tietoa. Esimerkiksi kuuluuko nuorten ääni verkkojulkisuudessa? Mitä voidaan sanoa nuorten valtautumisen prosesseista sivustojen käytön eri konteksteissa? Nuorten kansalaissivustojen sisältöjä ja muotoja on tutkimuksissa analysoitu,

Artikkelissa tarkastellaan nuorten yhteiskunnallista osallistumista tietoverkossa ja esitellään ensimmäisiä tuloksia hämeenlinnalaisnuorille tehdystä kyselystä ( $N=541)$. Kyselyssä selvitettiin nuorten tietoverkon käyttöä ja osallistumista nuorten paikallista kansalaisvaikuttamista edistävällä Vaikuttamo-sivustolla. Artikkelissa todetaan digitaalisen viestinnän olevan nuorille arkipäivää, vaikka nuoret ovatkin hyvin erilailla aktiivisia verkossa. Nuoria lähestytään tulevaisuuden tekijöinä, jotka perinteisen poliittisen osallistumisen sijaan voisivat olla kiinnostuneita vuorovaikutteisen teknologian ja verkkojulkisuuden mahdollistamista osallistumisen muodoista. Artikkelissa tuodaan esille, että nuorille suunnattuja kansalaissivustoja on paljon, mutta tietoa niiden merkityksestä nuorille on vielä vähän. Vaikuttamo-sivuston todetaan lisänneen nuorten vaikutusmahdollisuuksia yhdessä aktiivisten koulujen ja opettajien kanssa. Artikkelin mukaan mediapedagoginen tuki nuorten osallistumiselle tietoverkossa on tärkeää. Mediapedagogista tukea pohditaan artikkelissa oppimista osallistumisena yhteisöissä korostavan käytäntöyhteisö-käsitteen kautta. mutta arvioinnit näiden verkkoprojektien merkityksestä nuorille käyttäjille ovat vasta alkuvaiheessa.

Tapaustutkimuksemme ${ }^{1}$ kohteena on nuorten kansalaisvaikuttamista edistämään pyrkivä Vaikuttamo-sivusto ${ }^{2}$, joka julkaistiin vuonna 2002. Vaikuttamo on esimerkki paikallisesti toteutetusta nuorten kansalaissivustosta, jota voi jo arvioida käyttäjien näkökulmasta ja projektikokonaisuutena. Keväällä 2005 toteutimme kyselyn hämeenlinnalaisten yläluokkien ja lukioiden 14-18-vuotiaiden oppilaiden keskuudessa $(\mathrm{N}=541)$. Lähes puolet sivuston käyttäjistä katsoo vaikuttamismahdollisuuksiensa lisääntyneen projektin aikana, varsinkin keskustelufoorumeihin osallistuneet nuoret. Merkityksellinen tekijä prosessissa on tietoverkon rinnalla ollut koulu. Tulokset herättävät kysymyksiä mediapedagogisen tuesta, joka voisi 
kiinnittyä esimerkiksi nuorten toimintaan ja yhteisölliseen oppimiseen (virtuaalisissa) käytäntöyhteisöissä.

\section{Nuoret verkossa eri tavoin aktiivisia}

Viisi vuotta sitten Denis McQuail (2000) totesi, ettei digitaalisen teknologian ja verkottumisen kehitys ole vielä radikaalisti muuttanut kansalaisyhteiskuntaa, esimerkiksi politiikan tekemisen tapoja tai kaventanut sosiaalisia ja tiedollisia kuiluja. Edelleen vuonna 2005 voidaan allekirjoittaa sama toteamus, kun tutkimuksissa raportoidaan esimerkiksi kasvavista digitaalisista ja sosioekonomisista kuiluista ja tietoverkon käyttöönoton pulmista hallitusten aktivoivista toimista huolimatta (esim. Räsänen 2005; Olsson, Sandström \& Dahlgren 2003; Sirkkunen \& Kotilainen 2004).

Pekka Räsänen $(2005,23,32)$ pitää näitä kehittyneitä kuiluja osin pysyvinä, koska teknologian käyttö vaatii vastaavanlaisia taitoja ja kompetensseja kuin perinteinen lukutaitokin. Hän luokittelee kuitenkin nuoret viestintäteknologian varhaisiksi omaksujiksi (early adapters) yhdessä korkean koulutuksen ja hyvän sosioekonomisen aseman omaavien aikuisten kanssa. Sonia Livingstone ja Magdalena Bober (2005) ovat havainneet nuortenkin keskuudessa sosiaaliset erot, jotka ovat siirtyneet verkkoon pääsystä tietoverkkojen käytön laatuun: esimerkiksi käytettävissä olevaan aikaan verkossa, digitaalisiin taitoihin ja näiden myötä erilaisiin online- ja osallistumisen aktiviteetteihin.

Tapaustutkimukseemme liittyvän kyselyn ${ }^{3}$ analysoiduista 521 nuoresta 66,5\% (346) on käynyt Vaikuttamo-sivuilla koulussa tai vapaa-aikana, ja sivuilla kävijöissä on eniten 16-18-vuotiaita. Kuten brittinuorten osallistumista tietoverkossa tutkineet Sonia Livingstone, Magdalena Bober ja Ellen Helsper (2004) ovat havainneet, enemmistö nuorten kansalaissivuilla kävijöistä on tässäkin tapauksessa tyttöjä: Vaikuttamossa kävijöistä $62 \%$ (214) on tyttöjä ja poikia on $38 \%$ (130). Sivuilla käymättömissä ( $\mathrm{N}=166)$ poikia on taas tyttöjä enemmän.

Lomakkeen avulla selvitimme yleisesti nuorten Internetin ja matkapuhelimen käyttöä, kokemusta omasta digitaalisen osaamisen tasosta, verkkosivuilla osallistumista sekä kansalaisvaikuttamiseen tähtäävillä sivuilla vierailemista. Juuri samantyyppisiä asioita ovat brittinuorten kohdalla tutkineet Livingstone, Bober ja Helsper (2004). Sen sijaan nuorten kansalaissivuston käyttöön liittyviä muita kyselyjä emme ole toistaiseksi löytäneet. Vaikuttamoon liittyvät kysymykset koskivat esimerkiksi sivuston mielenkiintoisimpia osioita, osallistumista toimintoihin sivuilla sekä nuorten kokemuksia tieto- ja viestintätekniikan taitojen ja vaikutusmahdollisuuksien lisääntymisestä. Lisäksi kysyimme, miten päättäjien pitäisi nuorten mielestä osallistua Vaikuttamossa ja miten sivustoa tulisi nuorten mielestä kehittää.

Kyselymme analyysit ovat vielä kesken, mutta alustavat tulokset tietoverkon yleisistä käyttötavoista ovat samansuuntaisia kuin brittinuorilla. Vastaajina olleiden tyttöjen ja poikien toiminta tietoverkossa eroaa tilastollisesti erittäin merkitsevästi $(p<.001)$ esimerkiksi verkkopelien pelaamisessa, tiedostojen lataamisessa, uutisten seuraamisessa ja kotisivujen rakentamisessa: pojat toteuttavat näitä toimintoja useammin kuin tytöt. Myös Vaikuttamossa kävijöiden ja käymättömien nuorten toiminnassa tietoverkossa on eroa $(p<.05)$. Vaikuttamossa kävijät chattailevat, vierailevat keskustelufoorumeilla tai uutisryhmissä, etsivät informaatiota koulutöihin, seuraavat uutisia ja lukevat verkkolehtiä useammin kuin nuoret, jotka eivät käy Vaikuttamossa.

Eurooppalaisten lasten ja nuorten mediaympäristöä vertaillutta tutkimusprojektia vetänyt Sonia Livingstone $(2001,331)$ toteaa, että Euroopassa on merk- 
kejä yhtenäisestä lasten ja nuorten mediakulttuurista, johon liittyy kaupallisuus, vapaa-ajan mahdollisuuksien moninaisuus sekä kodin suuri merkitys yksityisenä vapaa-ajan paikkana. Lasten ja nuorten mediaympäristöissä on kuitenkin myös eroja: perhe-elämään ja vapaa-aikaan liittyvät kulttuuriset perinteet kehystävät niin tietoverkkoon pääsyä ja mediankäyttöä kuin elämäntyylejä ja valintoja.

Digitaalinen viestintä tuntuu olevan joka tapauksessa nuorille arkipäivää. Livingstonen ym. (2005) tutkimuksen brittinuorista 7 \% ja kyselyymme vastanneista hämeenlinnalaisnuorista vain $5 \%$ (24) kokee itsensä aloittelijaksi Internetin käyttäjänä. Tämä lienee syynä siihen, että Vaikuttamossa osallistuminen ei ole nuorten mielestä lisännyt heidän tieto- ja viestintätekniikan taitojaan: vain $9 \%$ (31) Vaikuttamossa käyneistä nuorista on sitä mieltä, että taidot ovat lisääntyneet.

Digitaalista teknologiaa ei kuitenkaan ehkä vielä ole osattu riittävän laajasti ja monipuolisesti hyödyntää nuorten osallistumisen tukena. Esimerkiksi kolmenkymmenen suomalaisnuoren kännykän ja Internetin käyttöä tutkineet Kaisa Coogan ja Sonja Kangas (2001, 49-59) ovat todenneet nuorten näkevän Internetin pääasiassa kommunikaatiovälineenä ja tietovakkana. Cooganin ja Kankaan mukaan nuoret eivät ajattele Internetiä omien töiden tai ajatusten julkaisukanavaksi ja vain harvat nuorista toteuttavat itseään tietoverkossa tai osallistuvat aktiivisesti erilaisten sisältöjen tuottamiseen. Haastatteluissa nuoret eivät esimerkiksi tuoneet esiin kotisivujen tekemisen merkitystä omien ajatusten julkaisukanavana.

\section{Nuoret tulevaisuuden tekijöinä}

Nuorisotyön historiaa tutkineen Juha Niemisen (1995) mukaan juuri nuoriso on nähty suomalaisen yhteiskunnan tulevaisuuden voimavarana itsenäisyyden ajan alusta lähtien muun muassa kirkon ja järjestöjen piirissä. Politiikka ja yhteiskunnallinen osallistuminen ovat olleet osa puoluepoliittisesti sitoutunutta nuorisotoimintaa 1900-luvun alun teollistumisesta lähtien. Nieminen raportoi nuorten osallistumisen poliittisiin järjestöihin vähentyneen 1960- ja 1970-luvuilla, mutta asiasta ryhdyttiin huolestumaan vasta 1980-luvulla. Erilaiset nuorten osallisuushankkeet ovat olleetkin sittemmin osa järjestöjen ja kunnallista nuorisotyötä tavoitteena aktivoida ja kasvattaa nuoria osallistuviksi kunnon kansalaisiksi (ks. esim. Paakkunainen 2004).

Tommi Hoikkala, Sofia Laine ja Jyrki Laine (2005) pohtivat nuorten osallistumisen ja kapinan kehitystä Karl Mannheimin sukupolviteorian pohjalta, jolloin noin 17. ikävuoteen osuu herkkä, mieltä ja kollektiivisia kokemuksia muotoileva ikä. Kirjoittajat määrittelevät erilaisia poliittisen osallistumisen sukupolvia, joista nykynuoret edustavat yksilöllisen pakkovalinnan sukupolvea "kiivaan muuttoliikkeen ja informaatioteknologian sovellusten läpäisemässä elämänmaisemassa". Sukupolvea kuvaavat hyvin myös kuluttaminen ja kilpailu ja toisaalta globalisaatiokriittinen aktivismi eli osallistuminen ylikansallisiin asiakysymyksiin, esimerkiksi ympäristöön ja eläintensuojeluun liittyvään kritiikkiin. Kirjoittajien mielestä pahin paikka, johon tämä 1990-luvulla syntynyt nuoriso voisi joutua olisi 70-luvun poliittisen nuorisojärjestön kokous.

"Julkisuutta on nykyään enemmän kuin koskaan aiemmin, mutta kuilu kansalaisten ja vallanpitäjien välillä näyttää vain kasvavan. Miten tätä voidaan selittää?" kysyy mediatutkija Hannu Nieminen (2004). Hän kiinnittää pohdintansa erilaisiin sukupolvikokemuksiin entisessä yksisuuntaista joukkoviestintää korostaneessa yhteiskunnassa ja nykyisessä mediayhteiskunnassa, joka korostaa vuorovaikutteista mediaa. Niemisen mukaan aikuisten käsitykset kansalaisvaikuttamisestakin perustuvat menneen joukkoviestintäyhteiskunnan vaiheeseen, jolloin vaikuttami- 
sen tavoiksi määrittyivät esimerkiksi äänestäminen, yhdistystoiminta, valitukset viranomaisille ja yleisönosastokirjoitukset. Peter Dahlgreninkin mukaan yksilöt ja yhteisöt ovat etsimässä uusia tapoja toteuttaa demokratiaa ja tässä media voi joko edistää tai rajoittaa toimia, ja hän nostaa esiin juuri nuoret tulevina yhteiskunnan toimijoina ja muutoksen tekijöinä (Dahlgren 2000; vrt. Buckingham 2003).

Hannu Nieminen saa tukea Villiina Hellstenin ja Tuomo Martikaisen (2004) tuloksista helsinkiläisten 18-30-vuotiaiden puoluesamaistumisen, asenteiden ja äänestysaktiivisuuden kehittymisestä, joita he ovat tutkineet kolmella kyselyllä vuosina 1988-1999. Tutkijoiden mielestä nuoret eivät ole kyllästyneet politiikkaan sinällään vaan sen tekotapaan eli muun muassa yllä mainittuihin ritualistisiin osallistumistapoihin. Tutkijat toteavat puolueiden mallin säilymisen olevan kiinni politiikan toteuttamisen uudistumisesta kansalaisten toiveiden mukaan (mt., 154-155).

Jaana Hujasen ja Sari Pietikäisen (2003) tutkimustulokset osoittavat, että nuorille omalla paikkakunnalla vaikuttaminen esimerkiksi ottamalla yhteyttä toimittajiin ei välttämättä ole kiinnostava osallistumisen tapa. Monet nuoret kokevat osallistumiseksi jo ajankohtaisista asioista tietämisen ja niistä keskustelemisen, ja ennemmin omassa ystäväpiirissä kuin tätä laajemmassa julkisuudessa.

Liisa Horelli, Tiina Sotkasiira ja Lotta Haikkola (2004, 141-142) ovatkin havainneet, että nuorten poliittinen asema on dynaaminen, muuttuva tila, jossa he etsivät ja oppivat tapoja toimia. Aktiiviset ja motivoituneet nuoret toimivat myös poliittisesti, mutta "tavalliset" nuoret eivät ole niin kiinnostuneita perinteisistä kansalaisvaikuttamisen tavoista, mutta tämä jako ei kuitenkaan ole pysyvä tila. He ehdottavat, että sensitiivisellä tuella voidaan kehittää nuorten kansalaiskulttuuria, esimerkiksi hyödyntäen tietoverkkoja. Joidenkin kuntien ja seutujen nuorisotyössä media on jo otettukin mukaan toimintaan, esimerkiksi Helsingissä4, Pohjois-Karjalassa ${ }^{5}$ ja Inarissa ${ }^{6}$.

Vuorovaikutteinen teknologia on haastanut yleisöt (toimijat, käyttäjät, kuluttajat) mediatutkimuksen agendallekin aktiivisten yleisöjen ja sosiaalisen toiminnan teorian vauhdittamana. Lisääntyneet mahdollisuudet tietoverkoissa haastavat kehittämään ja tutkimaan osallistuvia viestinnän muotoja, joissa voi "jakaa ja vaihtaa informaatiota sekä kokea ja kehittää toimivia (tietokonevälitteisiä) suhteita" (McQuail 2000, 120; Servaes 2001). Yleisöjen aktiivisuutta tulisi kuitenkin tarkastella erikseen konteksteittain, koska se ei ole yksi yhtenäinen tapa osallistua aikuistenkaan keskuudessa (esim. McQuail 2000). Peter Dahlgrenin (2004) mukaan habermasilaisessa näkemyksessä on jätetty huomioimatta se, että ihmisillä on oikeus myös olla osallistumatta.

Dahlgren (2000; 2004) tarjoaa julkisuuden rakenteiden ja poliittisen osallistumisen rinnalle käsitettä kansalaiskulttuuri (civic culture) kulttuurintutkimuksellisena lähestymistapana, jossa nousevat esiin merkityksellisyyden, identiteetin rakentumisen ja sosiaalisen toimijuuden teemat. Kansalaiskulttuurissa kulttuuri korostuu kollektiivisesta merkityksen muodostuksesta jossain määrin. Tärkeinä elementteinä Dahlgren mainitsee relevantit tiedot ja kompetenssit, joihin lukeutuvat esimerkiksi teknologian saatavuus ja ihmisten viestinnälliset kompetenssit. Hän pitää mediaa yhtenä kansalaisuuden teknologiana yhdessä hallinnon ja kasvatuksen kanssa. Hänen mielestään tässä roolissa media voi palvella kansalaisuutta vahvistavana tai rajoittavana (disempower) tekijänä kansalaiskulttuurissa.

Erityisesti Internetin mahdollisuuksiin nuorten kansalaiskulttuureissa kiinnittävät huomionsa Carsten Yndigegn, Peter Waara ja Kari Paakkunainen (2005), jotka ovat vertailleet Itämeren maiden nuorten jälkikansallisten identiteettien rakentumista tietoverkon käyttöön kiinnittyvällä kyselyllä Helsingissä, Kööpenhaminassa, Tukholmassa, Tallinnassa ja Pietarissa. Tulosten mukaan tietoverkkoa käyttävät eniten poliittisena ja kulttuurisena lähteenä ja verkottumisen mahdollisuutena 
Tallinnan ja Pietarin nuoret, joilla on tarve esimerkiksi kasvattaa tietouttaan näillä alueilla (mt., 138-139). Kuten brittitutkijatkin (Livingstone ym. 2004), he löytävät aineistosta vähemmistönä vastaajaryhmän, joka käyttää tietoverkkoa poliittiseen osallistumiseen esimerkiksi ympäristökysymyksissä (mt., 146). Tutkijat katsovat Internetin avanneen kentän dialogiselle, osallistuvalle kulttuurille ja poliittiselle toiminnalle vastakohtana institutionaaliselle vallalle ja päätöksille.

Sonja Livingstone, Magdalena Bober ja Ellen Helsper (2004) jaottelevat nuoret tietoverkossa viestijöihin (interactors), yhteiskunnallisesti tietoisiin (civic minded) ja osallistumattomiin (disengaged). Viestijöille riittää esimerkiksi osallistuminen yleensä verkkokeskusteluissa tai kotisivujen rakentelu, kun yhteiskunnallisesti tietoiset haluavat osallistua verkon kautta äänestyksiin, kansalaisadresseihin ja erityisesti yhteiskunnalliseen keskusteluun. Osallistumattomatkin haluaisivat osallistua, mutta heiltä puuttuu sujuva pääsy tietoverkkoon ja taitoja. Livingstone päätyykin esittämään yhteiskunnallisesti painottunutta mediakasvatusta kouluihin. Lisäksi hän suosittelee nuorille suunnattujen yhteiskunnallisten verkkosivustojen tuottajille näiden sivustojen ulkoasun rukkausta nuorisoystävällisemmiksi. Tutkijat peräänkuuluttavat lisää systemaattista tutkimusta näistä verkkoprojekteista ja niiden merkityksestä nuorille. Myös Kathryn Montgomery, Barbara Gottlieb-Robles ja Gary O. Larson (2004) raportoivat useimpien yhdysvaltalaisten nuorille suunnattujen verkkoprojektien arvioinnin olevan vasta alkuvaiheessa.

\section{Nuorten kansalaissivustot ja nuorten ääni}

Internetissä on julkaistu viimeisten viiden vuoden aikana varmaankin tuhansia juuri nuorille suunnattuja kansalaissivustoja eri puolilla maailmaa, enimmäkseen erilaisten nuorten kehitystä tukemaan pyrkivien järjestöjen ja muiden organisaatioiden toimesta. (ks. useita esimerkkejä USA:sta Montgomery, Gottlieb-Robles \& Larson 2004). Amerikkalaistutkijat pitävät tätä kansalaisverkkosektoria uudenlaisena lajityyppinä nuorten kansalaiskulttuurissa. Analysoituaan 300 nuorten kansalaissivustoa Yhdysvalloissa he ovat havainneet näiden sivustojen toimivan vaihtoehtoisena nuorten mediana pääosin nuorille suunnatussa kaupallisessa digitaalisessa mediaympäristössä. Näillä sivustoilla nuorille tarjotaan pohdittavaa ja osallistumisen mahdollisuuksia poliittiseen, yhteiskunnallisia asioita edistävään elämään tavoitteena edistää yhteistä hyvää. Sivustojen tuottajina toimivat nuorten kansalaisyhteiskuntaa tukevat järjestöt ja organisaatiot, mutta ne ovat syntyneet myös yksityisten ja nuorten itsensä aloitteista. Myös kaupallinen media on ottanut kansalaisuusteemoja hybrideina portaaleihinsa.

Montgomery, Gottlieb-Robles ja Larson (2004) pitävät suurinta osaa näistä sivustoista marginaalisina suhteessa koko digitaaliseen mediaympäristöön. Yhteisinä tavoitteina sivustoprojekteissa he mainitsevat tietouden levittämisen erityisteemoista, nuorten äänen kuuluviin saattamisen, nuorison kansalaisuuden vahvistamisen ja muutosten edistämisen taidot. Nämä verkkosivustot siis tarjoavat informaatiota, edistävät erilaisten taitojen rakentumista ja pyrkivät rohkaisemaan nuoria osallistuviksi kansalaisiksi (vrt. Nieminen 1995).

Tutkimuksemme kohteena oleva Vaikuttamo.net on osa vuonna 2001 Hämeenlinnassa käynnistynyttä kaupungin opetustoimen ja Hämeenlinnan seudun mediakeskuksen Oppilaat paikallisina vaikuttajina -hanketta. Sivusto on suunnattu peruskoulun ala- ja yläluokkien sekä lukion oppilaille. Sivuston toiminta käynnistettiin kaupunginjohtajien ja nuorten yhteisellä chat-keskustelulla (Kantola 2003).

Vaikuttamo-projektin vetäjä Mika Kantola kertoo, että Oppilaat paikallisina vaikuttajina -hankkeen tavoitteena on eri vaikuttamisen keinot hallitseva nuori 
kuntalainen, jolla on halu vaikuttaa ja kehittää omaa ympäristöään. Vaikuttamosivustolla on keskeinen osa tämän tavoitteen toteuttamisessa. Vaikuttamon tarkoitus on toimia kansalaisvaikuttamisen taitojen oppimisen tukena ja vaikuttamisen kanavana sekä vuorovaikutteisena oppimisympäristönä. Tarkoituksena on tuoda myös esiin mahdollisuuksia hyödyntää tiedotusvälineitä kansalaisvaikuttamisessa. (Kantola 2003.)

Vaikuttamo-sivusto rakentuu kahdesta peruselementistä: informatiivisesta fakta-osiosta ja vuorovaikutteisesta sekä osin toimituksellisesta keskustelu- ja ajankohtaisosiosta. Fakta-osion Oma kunta -osassa on tietoa kunnan päättäjistä ja päätöksentekoprosesseista. Vaikkaajan käsikirjassa kerrotaan erilaisista kansalaisen vaikuttamismahdollisuuksista, ja Mediat-osassa annetaan ohjeita yleisönosastokirjoituksen tai lehdistötiedotteen laatimiseen. Vuorovaikutteiseen keskustelu- ja ajankohtaisosioon sisältyy Vaikuttamon keskusteluympäristö, Puhujan parkki. Keskustelut liittyvät esimerkiksi oman kaupungin asioihin, kouluun ja vapaa-aikaan. Tarkkailulistalla nostetaan esiin kaupungin päätöksenteossa nuoria koskettavia asioita ja seurataan niiden käsittelyn etenemistä. Nuoret tuottavat sivulle Viikon vaikuttaja ja Kuukauden tekijä -haastatteluita, joissa esitellään aktiivisia nuoria ja kaupunkilaisia. Vaikuttamossa julkaistaan lisäksi oppilaiden kirjoittamia ja kuvaamia juttuja ja projektitöitä. Juttujen tuottaminen liittyy kiinteästi koulujen toimintaan: jokaisessa Hämeenlinnan yläkoulussa ja lukiossa on toimituskunta, joka vastaa juttujen teosta.

Kyselystämme käy ilmi, että nuoret ovat kiinnostuneita Vaikuttamo-sivuston nuorten itse tuottamista ja vuorovaikutteista osioista, kuten jutuista ja Viikon vaikuttaja -haastattelusta sekä keskustelufoorumi Puhujan parkista (katso kuvio 1). Vähemmän nuoria kiinnostaa sivuston informatiivinen puoli (esim. Vaikkaajan käsikirja, Tarkkailulista). Sekä pojat että tytöt osallistuvat sivuilla gallupiin ja Puhujan parkkiin, mutta tytöt kirjoittavat juttuja poikia enemmän.

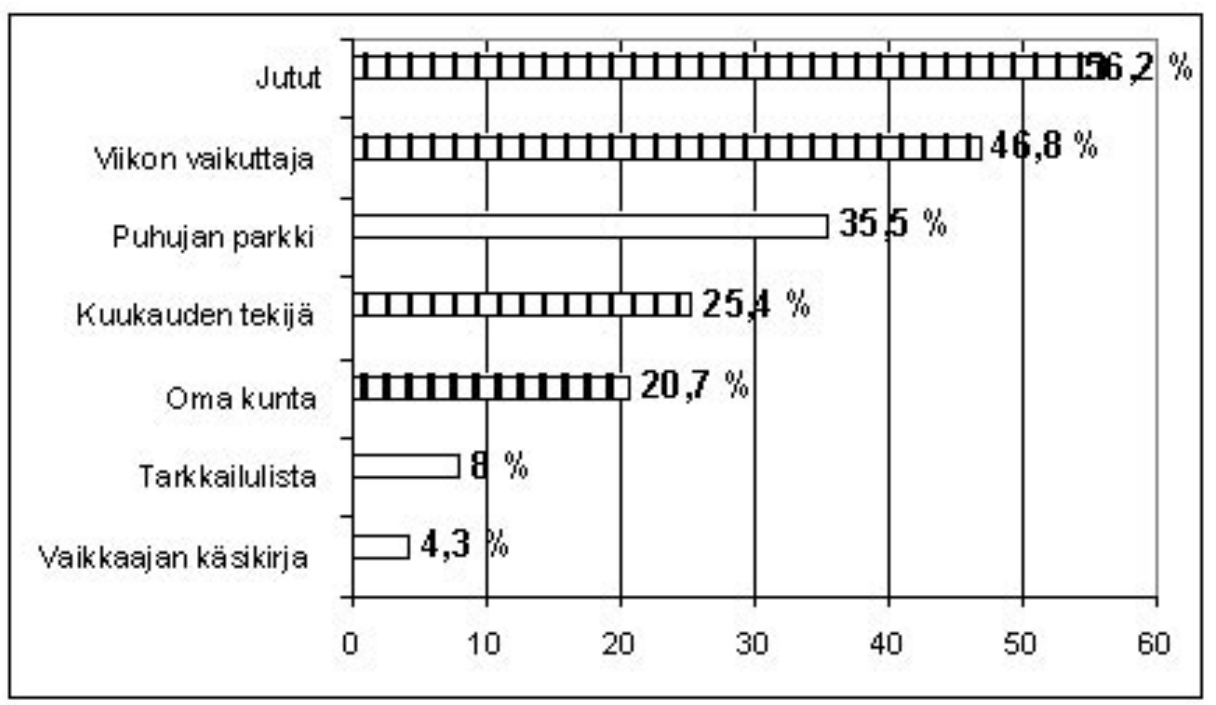

Kuvio 1. Mitkä Vaikuttamon osiot ovat mielestäsi mielenkiintoisimmat? Valitse enintään kolme. ( $N=299)$ 
Livingstone, Bober ja Helsper (2004) kysyvät, tarjoavatko nuorille suunnatut kansalaissivustot todella mahdollisuuden osallistua vai pelkästään lisää informaatiota? Analysoituaan brittiläisiä nuorten kansalaissivustoja he päätyvät pitämään niitä nuorten näkökulmasta tylsinä liian virallisella tyylillään. Heidän mielestään nuoret asemoidaan näillä sivuilla kasvuvaiheessa oleviksi kansalaisiksi (citizens-inwaiting) eikä todellisiksi vaikuttajiksi. Heidän tilastollinen tutkimuksensa nuorten keskuudessa osoittaa, että nuoret ovat halukkaita ja valmiita kokeilemaan erilaisia asioita. Motivaation puutetta esiintyy silloin, jos nuoret eivät löydä vastakaikua aloitteisiinsa: todellisen vaikuttamisen tunne on merkittävä tekijä.

Vaikuttamo näyttää lisänneen nuorten vaikutusmahdollisuuksia, sillä lähes puolet eli 48,56 \% (168) sivustolla kävijöistä kokee vaikutusmahdollisuuksien lisääntyneen. Erityisesti vuorovaikutteisessa keskusteluosiossa Puhujan Parkissa osallistuvat ovat tätä mieltä. Millaisiin asioihin nuoret ovat kokeneet vaikuttaneensa? Tässä pari esimerkkiä lomakkeen avoimista vastauksista:

Koulun ruuat. Sain sanottua asiani ja siitä puhuttiin jälkeenpäin foorumissa paljonkin.

Peili alikulkutunneliin! Me saatiin se sinne.

Skeittihalli

Löysimme myös merkkejä siitä, että Vaikuttamo-sivustoon liittyvä toiminta olisi saattanut vähentää sosioekonomista epätasa-arvoa paikallisesti liittyen kansalaistaitoihin ja vaikutusmahdollisuuksiin. $79 \%$ vastaajista, joiden äiti on työelämän ulkopuolella, ja 47 \% vastaajista, joiden äiti on työelämässä, kokee vaikutusmahdollisuuksiensa lisääntyneen (taulukko 1). Ero on tilastollisesti merkitsevä ( $p=.007$ ). Analysoimme tulosta lisäksi logistisen regressioanalyysin avulla tarkastellen, mikä muu voisi selittää nuorten kokemusta vaikutusmahdollisuuksien lisääntymisestä. Yksikään muista kymmenestä analyysissa tarkastellusta muuttujasta7 ei osoittautunut merkitseväksi selittäjäksi. Äidin tilanne työelämässä (opiskelija, työtön, eläkeläinen) selitti 8,5 \% vaikutusmahdollisuuksien lisääntymisen kokemuksesta. Tulos on mielenkiintoinen ja vaatisi tarkastelua myös laadullisesti. Tulkinnassa on esimerkiksi huomioitava, että vastaajien määrä äiti työelämän ulkopuolella -ryhmässä on hyvin pieni $(\mathrm{N}=19)$.

\begin{tabular}{lccccccc}
\hline & \multicolumn{3}{c}{ Äiti työelämässä } & \multicolumn{3}{c}{$\begin{array}{c}\text { Äiti työelämän } \\
\text { ulkopuolella }\end{array}$} & \multicolumn{2}{c}{ Yhteensä } \\
\hline "Paljon tai vähän" & 127 & $(47 \%)$ & 15 & $(79 \%)$ & 142 & $(49 \%)$ \\
\hline "Ei ollenkaan" & 142 & $(53 \%)$ & 4 & $(21 \%)$ & 146 & $(51 \%)$ \\
\hline Yhteensä & 269 & $(100 \%)$ & 19 & $(100 \%)$ & 288 & $(100 \%)$
\end{tabular}

Taulukko 1. "Vaikuttamo on lisännyt mahdollisuuksiani vaikuttaa koulussa, harrastuksissa tai muualla"

Vaikuttamo-sivustoa voidaan pitää tyypillisenä nuorten kansalaissivustona. Projektia toteuttaa julkinen organisaatio eli kaupunki tavoitteenaan sitouttaa nuoria kansalaiskulttuuriin ja vaikuttamaan paikallisten yhteisten asioiden hoitoon ja kehittämiseen. Sivusto on informatiivinen, mutta sisältää myös kokemuksellisia ja vuorovaikutteisia keskustelu- sekä nuorten journalistisia osioita. Tulokset osoitta- 
vat, että tässä projektissa nuorille tarjotaan mahdollisuus oman äänen kuuluville saamiseen ja kuulluksi tulemiseen. Näin Vaikuttamo-projekti on edistänyt omalta osaltaan paikallista nuorten kansalaiskulttuuria ja vuorovaikutteista sekä vaihtoehtoista julkisuutta, jossa nuoret ovat voineet aktiivisesti toimia halutessaan tuottajina ja ilmaisijoina (vrt. Livingstone, Bober ja Helsper 2004; Montgomery, Gottlieb-Robles ja Larson 2004; McQuail 2000, 120; Servaes 2001). Mutta miten nuorten ääni kuuluu paikallisesti muussa mediajulkisuudessa? Entä kaupungin hallinnossa laajemmin?

Tulokset osoittavat myös, ettei toiminta tavoita kaikkia kaupungin kohderyhmäikäisiä oppilaita, kun 521 vastaajasta 166 ei ole käynyt sivustolla. Projekti ei siis ole kattanut kaikkia kouluja tai opettajia. Tämä ei ole ihme, koska aikaisemmissa tietoverkon käyttöön oton tutkimuksissa on myös havaittu, että digitaalisen teknologian kiinnittäminen jo omaksuttuihin rutiineihin vaatii aikaa, tietoa ja osapuolten välistä neuvottelua (ks. esim. Sirkkunen \& Kotilainen 2004).

\section{Mediapedagogisen tuen paikka}

Kyselyn perusteella voidaan sanoa, että tietoverkko voi olla osavastaus, kun halutaan edistää nuorten (ja aikuisten) yhteiskunnallista osallistumista. Digitaalinen teknologiakin suo mahdollisuuksia uusien osallistumistapojen kehittymiselle. Yksistään verkkoprojektina Vaikuttamo ei ole kuitenkaan tuottanut esimerkiksi nuorten tunnetta vaikutusmahdollisuuksiensa lisääntymisestä, vaan prosessissa on ollut merkittävä rooli myös aktiivisilla kouluilla ja opettajilla. Kouluyhteistyö on taannut kestävän kehityksen yksittäisten sivuston käyttökertojen sijasta. Montgomeryn, Gottlieb-Roblesin ja Larsonin (2004) mukaan tällainen jatkuva tuettu käyttö on tärkeää, jos sivustojen halutaan toimivan kansalaistaitojen ja -kulttuurin oppimisen lähteinä. Tulokset osoittavat, että juuri vuorovaikutteiset ja kokemukselliset osiot ja kokemukset liitettynä myös kouluyhteistyöhön ovat tärkeitä.

Pedagogisen tuen merkitys on havaittu myös aikuisten kansalaisverkkokokeiluissa. Esimerkiksi tamperelaisen Mansetorin ja oululaisen Naapurit.net-sivuston kehittämisessä asukkaiden ja yhteisöjen vahvistumiseen ja verkkojulkisuudessa osallistumisen edistämiseen tarvittiin seuraavia elementtejä, joista Vaikuttamossa toteutuvat ainakin verkkojulkisuus ja mediapedagoginen tuki (Kotilainen 2004, 296):

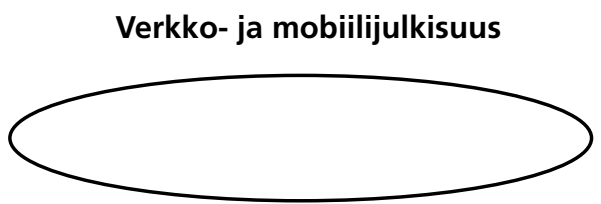

\section{Viestintätarpeiden tiedostaminen Mediapedagoginen tuki}

Kuvio 2. Kansalaisten verkkojulkaisemisen ehdot

Tärkeätä on ensin taata esimerkiksi nuorille pääsy verkkojulkisuuteen, herätellä viestintätarpeita ja tarjota viestinnän taitojen kehittymisen mahdollisuus. Verkkoon pääsyn lisäksi tarvitaan siis ohjelmistoja ja mediapedagogista tukea, joka voi olla myös esimerkiksi vertaistukea yhteisössä. 
Montgomery, Gottlieb-Robles ja Larson $(2004,127)$ toteavat, että nuorten sivut voisivat tukea parhaiten aktiiviseksi kansalaiseksi kasvua silloin, kun sivustolla toimii jatkuvaan toimintaan sitoutunut yhteisö, kuten nuorisoryhmä, koulu tai kansalaisjärjestö. Mediapedagogisesti nuorten kansalaisvaikuttamiseen tähtääviä sivustoja voisikin lähestyä juuri verkkoyhteisöinä. Millaista oppiminen tällaisessa yhteisössä voisi olla? Miten oppimista ja aktiivista kansalaisuutta verkkoyhteisöissä voisi tukea?

Angela Thomas (2005a) on tutkinut nuorten toimintaa ja oppimista roolipelaamiseen liittyvässä virtuaaliyhteisössä Gathering of the Elves. Thomas lähestyy oppimista virtuaaliyhteisössä Jean Laven ja Etienne Wengerin (Wenger 1998; Lave \& Wenger 1991) käytäntöyhteisö-käsitteen (community of practice) kautta. Käsitettä on perinteisesti sovellettu aikuisten työssäoppimiseen tai organisaatioiden tiedonhallintaan. Virtuaalisista käytäntöyhteisöistä on kirjoitettu esimerkiksi yhteisölliseen verkko-oppimiseen liittyen. Lasten tai nuorten oppimisen tai yleensä verkkoyhteisöjen tutkimuksessa käsitettä on käytetty vähemmän. (Thomas 2005a; Johnson 2001.) Käytäntöyhteisö voi kuitenkin syntyä ja toimia missä tahansa, esimerkiksi koulussa tai tietoverkossa. Lähtökohtana on, että oppiminen on sosiaalista toimintaa ja osallistumista yhteisöissä. Lyhyesti, käytäntöyhteisö on ryhmä ihmisiä, jotka vuorovaikutuksessa keskenään oppivat ja syventävät osaamistaan yhteisestä kiinnostuksen kohteesta tai ongelmakentästä. (Wenger 2004.)

Oppimisessa käytäntöyhteisöissä on Etienne Wengerin (1998) mukaan neljä keskeistä elementtiä: merkitys, käytäntö, yhteisö ja identiteetti. Oppimiseen siis liittyy: (1) oman elämän ja maailman kokeminen merkityksellisenä, (2) yhteisiä käytäntöjä eli jaettuja resursseja, viitekehyksiä ja näkökulmia, jotka ylläpitävät sitoutumista yhteisön toimintaan, (3) yhteisö, joka tukee ja arvostaa jäsentensä osallistumista sekä (4) identiteettien rakentamista yhteisön jäsenenä. (Wenger 1998, 4-5.) Oppimisessa käytäntöyhteisöissä näyttäisi tulevan esiin juuri sellaisia asioita, joita 2000-luvun niin sanotussa yhteisöllisyyden vaiheen mediapedagogiikassa korostetaan (Kotilainen \& Kivikuru 1999, 26-27). Kun mediakasvatuksen tavoitteena on tukea nuorten kasvua aktiivisiksi toimijoiksi ja osallistuviksi kansalaisiksi, tärkeää on käytännön toiminta ja tekemällä oppiminen sekä yhteisön jäseneksi tuleminen ja jäsenenä toimiminen. Mediapedagogisen toiminnan on myös oltava nuorille merkityksellistä ja tarjottava mielekkäitä mahdollisuuksia identiteettien rakentamiseen.

Angela Thomas (2005a) löysi tutkimuksessaan käytäntöyhteisön toiminnan ja oppimisen tapoja nuorten virtuaaliyhteisöstä. Nuoret oppivat osallistumalla yhteisön toimintaan ja käytäntöjen luomiseen. Oppiminen tapahtui vuorovaikutuksessa muiden kanssa muun muassa yritysten ja erehdysten, aivoriihien, kokeilujen ja tarinoiden kirjoittamisen kautta. Toimiessaan tässä yhteisössä nuoret saivat mahdollisuuksia esimerkiksi itsensä ilmaisuun ja vallankäytön harjoittelemiseen. Oppimista motivoi erityisesti halu kuulua yhteisöön. Virtuaaliyhteisössä nuoret myös oppivat vertaisiltaan: oppimiseen ei tarvittu välttämättä perinteiselle kasvatukselle ja koulutukselle tyypillistä ekspertti-noviisi-suhdetta. (Thomas 2005a, 27-28, 37.)

Mediapedagogiselta kannalta, niin kouluissa, nuorisotyössä kuin kansalaisjärjestöissä, olisi tärkeää kiinnittää huomio näihin nuorten toiminnan ja oppimisen tapoihin tietoverkossa. Esimerkiksi Sonia Livingstonen ja Magdalena Boberin (2004, 413-414) mukaan kasvatuksen ja koulutuksen näkökulmasta Internetiä pidetään usein pääasiassa vain informaation lähteenä, kun nuoret ovat kiinnostuneita nimenomaan tietoverkon kommunikaatiomahdollisuuksista ja oppivat juuri vuorovaikutuksen kautta. Thomas (2005b, tulossa) onkin havainnut, että opettajat alkavat vasta nyt laajemmin kiinnittää huomiota siihen, miten Internetin kautta ja 
avulla voi oppia hyödyntäen esimerkiksi verkon mahdollisuuksia yhteisöllisyyteen, keskusteluun ja julkaisemiseen. Myös Vaikuttamo on varmaankin ollut oppimisprosessi paikallisille opettajille. Kiinnostavaa on jatkossa selvittää sitäkin, millaisia käytäntöyhteisöjä sivuston piiriin on syntynyt.

On myös huomioitava, että mikä tahansa verkkosivusto ei ole käytäntöyhteisö. Käytäntöyhteisö rakentuu kolmen ulottuvuuden ympärille: (1) yhteinen kiinnostuksen kohde, tehtävä tai tavoite, (2) sitoutunut yhteisö ja (3) käytäntö eli esimerkiksi yhteisesti tuotetut ideat, informaatio, kertomukset tai dokumentit (Wenger 2004). Nuorten osallisuutta ja kansalaistaitoja tukevien verkkoyhteisöjen syntymiseksi tarvitaan siis pedagogista tukea. Esimerkiksi Vaikuttamo-sivustoa virtuaaliyhteisönä tarkastelleet Miia Kosonen, Outi Cavén ja Kirsimarja Blomqvist (2004, tulossa) toteavat Vaikuttamon ympärille syntyneen toimivan, nuorten aktiivista kansalaisuutta tukevan yhteisön. Olennaista tässä yhteisön syntymisessä on ollut toiminnan paikallisuus, henkilökohtaiset suhteet, yhteisön ulkopuolinen kontrolli (Mediakeskus) ja nuorten automaattinen jäsenyys yhteisössä kouluopetuksen kautta.

Mediapedagogisen tuen paikka voisi olla käytäntöyhteisöjen tapaisten verkkoyhteisöjen syntymisen ja toiminnan tukemisessa. Tuki voisi olla esimerkiksi yhteisen kiinnostuksen kohteen etsimistä tai yhteisön sitouttamista. Jos nuoret eivät ole löytäneet tai käyttäneet verkon mahdollisuuksia julkaisuun ja oman äänen kuulumiseksi saamiseen (Coogan \& Kangas 2001), tarvitaan ohjausta siihen. Jos nuorilta puuttuu esimerkiksi tiedottamisen tietotaito, suhteet paikalliseen mediaan, eivätkä nuoret koe itseään päteviksi toimijoiksi julkisuudessa (Horelli, Sotkasiira, Haikola 2004), tarvitaan tukea siihen. Tärkeää on antaa tilaa nuorten omalle toiminnalle ja oppimiselle verkkoyhteisössä eli luottaa siihen, että ei aina tarvita vanhempaa pedagogia. Kyse on siis mahdollisuuksien luomisesta.

\section{Viitteet}

1 Tapaustutkimus on osa Sirkku Kotilaisen laajempaa nuorisotutkimusprojektia, ja Leena Rantala työstää osin samasta aineistosta kasvatustieteen pro gradu -tutkielmaa.

2 www.vaikuttamo.net

3 Kyselymme kohteeksi valittiin keväällä 2005 Hämeenlinnan peruskouluissa ja lukioissa 900 iältään 14-18vuotiasta nuorta. Vastauksia saatiin kaikkiaan 541 kappaletta eli $60 \%$ tavoitteesta. Vastanneiden nuorten määrä on 19,5 \% kaikista Hämeenlinnan peruskoulujen 7.-9.-luokkien ja lukion 1.-3.-luokkien oppilaista. Lomakkeista 20 jouduttiin hylkäämään vastausten puutteellisuuden tai asiattomuuden vuoksi eli lopullinen vastaajamäärä on 521 .

4 www.hattu.net

5 www.ponu.net

6 www.lanuti.fi

7 Muuttujat olivat ikä, sukupuoli, äidin asema työelämässä, isän asema työelämässä, tietoverkkoon pääsy (kotona, koulussa tai muualla), verkkoyhteys matkapuhelimesta (kyllä tai ei), Internetin käyttöaika vuosina, kokemus itsestä Internetin käyttäjänä (aloittelija, keskiverto, keskivertoa parempi, ekspertti), arvioitu Internetin käyttöaika tyypillisenä arkipäivänä sekä arvioitu Internetin käyttöaika tyypillisenä viikonloppuna. Logistinen regressioanalyysi suoritettiin pakottavalla menettelyllä eli malliin otettiin mukaan kaikki mainitut muuttujat ja katsottiin, mitkä niiden painokertoimet mallissa ovat (ks. Metsämuuronen 2001, 82). 


\section{Kirjallisuus}

Buckingham, David (2003)

The Making of Citizens: Young People, News and Politics. London: Routledge

Coogan, Kaisa \& Sonja Kangas (2001)

Nuoret ja kommunikaatioakrobatia. 16-18-vuotiaiden kännykkä- ja Internetkulttuurit.

Nuorisotutkimusverkosto ja Elisa Communications. Saatavilla www-muodossa <http://www. nuorisotutkimusseura.fi>. Viitattu 29.7.2005.

Dahlgren, Peter (2004)

Theory, Boundaries and Political Communication. The Uses of Disparity. European Journal of Communication. 19 (1): 7-18.

Dahlgren, Peter (2000) The Internet and the Democratization of Civic Culture. Political Communication 17: 335-340.

Hellsten, Villiina \& Tuomo Martikainen (2002)

Nuorten poliittinen osallistuminen 1960-luvulta 2000-luvulle. Julkaisussa Silvennoinen, H. (toim.)

Nuorisopolitiikka Suomessa 1960-luvulta 2000-luvulle. Helsinki: Nuorisotutkimusverkoston julkaisuja 29, 137-155.

Hujanen, Jaana \& Sari Pietikäinen (2003)

Murros! Missä? Liikkeitä nuorten uutismedian seuraamisen käytänteissä. Tiedotustutkimus 26 (4-5): 51-61.

Hoikkala, Tommi \& Sofia Laine \& Jyrki Laine (toim.) (2005)

Mitä on tehtävä? Nuorison kapinan teoriaa ja käytäntöä. Helsinki: Nuorisotutkimusseuran julkaisuja 52.

Horelli, Liisa \& Tiina Sotkasiira \& Lotta Haikkola (2004).

Nuoret uuden osallistumiskulttuurin tienraivaajina. Teoksessa Paakkunainen, K. (toim.) Nuorten ääni ja kunnantalon heikko kaiku. Nuorisotutkimusseuran julkaisuja 46, 135-144.

Johnson, Christopher (2001)

A Survey of Current Research on Online Communities of Practice. Internet and Higher Education 4 (1), 45-60.

Kantola, Mika (2003)

Students and Local Decision-Making. Luentoteksti julkaistu sivustolla elearningeuropa.info. Saatavilla wwwmuodossa <http://www.elearningeuropa.info>. Viitattu 29.07.2005.

Kosonen, Miia \& Outi Cavén \& Kirsimarja Blomqvist (2004). Social and Political Impact of Virtual Communities - Case Vaikuttamo: a Successful Community to Serve Local Youth E-Democracy. Teoksessa Dasgupta, S. (toim.). Encyclopedia of Virtual Communities and Technologies. Saatavilla www-muodossa <http://www.tbrc.fi/ampers > . Viitattu 29.7.2005.

Kotilainen, Sirkku \& Ullamaija Kivikuru (1999) Mediakasvatus ihanteiden ja todellisuuden ristipaineissa. Teoksessa Kotilainen, S., Hankala, M. \& Kivikuru, U. (toim.) Mediakasvatus. Helsinki: Edita, 13-30.

Kotilainen, Sirkku (2004) Kansalaisten verkkomedia oppimisen yhteisönä. Teoksessa Sirkkunen, E. \& Kotilainen, S. (toim.) Toimijaksi tietoverkoissa. Raportti kansalaislähtöisen verkkoviestinnän mahdollisuuksista. Tampereen yliopisto, Journalismin tutkimusyksikön julkaisuja B44, 277-300.

Lave, Jean \& Etienne Wenger (1991) Situated learning. Legitimate peripheral participation. Cambridge University Press.

Livingstone, Sonia (2001) Children and Their Changing Media Environment. Teoksessa Livigstone, S. \& Bovill, M. (toim.) Children and Their Changing Media Environment. A European Comparative Study. Mahwah, New Jersey: Lawrence Erlbaum, 307-333.

Livingstone, Sonia \& Magdalena Bober \& Ellen Helsper (2004) Active participation or just more information? Young people's take up of opportunities to act and interact on the Internet. A research report from the UK Children go Online Project. Saatavilla www-muodossa <http://www.children-go-online.net > Viitattu 29.07.2005.

Livingstone, Sonia \& Magdalena Bober (2005)

UK Children Go Online: Final Report of key project findings. Saatavilla www.muodossa <http://www. children-go-online.net > Viitattu 29.07.2005.

Livingstone, Sonia \& Magdalena Bober (2004) Taking up Opportunities? Children's Uses of the Internet for Education, Communication and Participation. E-Learning 1 (3), 395-419. Saatavilla www-muodossa <http://www.wwwords.co.uk/ELEA>. Viitattu 29.07.2005.

McQuail, Denis (2000) McQuail's Mass Communication Theory. Sage Publications.

Metsämuuronen, Jari (2001) Monimuuttujamenetelmien perusteet SPSS-ympäristössä. Helsinki : International Methelp.

Montgomery, Kathryn \& Barbara Gottlieb-Robles \& Gary O. Larson (2004) Youth as E-Citizens: Engaging the Digital Generation. Center for Social Media. School of Communication in American University. Saatavilla www-muodossa <http://www.centerforsocialmedia.org>. 29.7.2005.

Nieminen, Hannu (2004) Kansalaisvaikuttaminen mediayhteiskunnassa. Puheenvuoro tutkimuksen tarpeista. Teoksessa Borg, S. (toim.) Mahdollisuuksien maa. Kartoitusta ja puheenvuoroja kansalaisvaikuttamisen tutkimuksesta. Oikeusministeriön julkaisuja 2004:10, 118-124. 
Nieminen, Juha (1995)

Nuorisossa tulevaisuus: suomalaisen nuorisotyön historia. Helsinki: Nuorisotutkimusseura r.y. ja Lasten keskus Oy.

Olsson, Tobias \& Håkan Sandström \& Peter Dahlgren (2003)

An Information Society for everyone? Gazette: The International Journal for Communication Studies. 65 (4-5): 347-363.

Paakkunainen, Kari (toim.) (2004)

Nuorten ääni ja kunnantalon heikko kaiku. Nuoret kunnallisessa demokratiassa ja paikallisissa

vaikuttajaryhmissä. Helsinki: Opetusministeriö ja Nuorisotutkimusseura r.y. Nuorisoasiain neuvottelukunnan julkaisuja 29.

Räsänen, Pekka (2005)

Tieto- ja viihdekulutuksen muotoutuminen eri väestöryhmissä. Sosiologia 42 (1): 19-34.

Servaes, Jan (2001)

Participatory Communication Research for Democracy and Social Change. Teoksessa Richards, M., Thomas, P.N. and Nain, Z. (toim.) Communication and Development: The Freirean Connection. New Jersey: Hampton Press.

Sirkkunen, Esa \& Sirkku Kotilainen (toim.) (2004)

Toimijaksi tietoverkoissa. Raportti kansalaislähtöisen verkkoviestinnän mahdollisuuksista. Tampereen yliopisto, Journalismin tutkimusyksikön julkaisuja B44.

Thomas, Angela (2005a)

Children Online: Learning in a Virtual Community of Practice. E-Learnig 2 (1), 27-38. Saatavilla wwwmuodossa <http://www.wwwords.co.uk/ELEA>. Viitattu 29.7.2005.

Thomas, Angela (2005b, tulossa)

Cyberspace, Cybercommunity, Cyberculture, Cybercitizenship. Teoksessa Lankshear, C., Knobel, M., Leu, D. \& Cairo, J. (toim.) The Handbook of New Literacies Research. Mahwah, New Jersey: Lawrence Erlbaum.

www.vaikuttamo.net. Hämeenlinnan Mediakeskuksen julkaisema nuorten sivusto. Saatavilla www-muodossa <http://www.vaikuttamo.net >. Viitattu 29.7.2005.

Wenger, Etienne (1998)

Communities of Practice. Learning, Meaning and Identity. Cambridge University Press.

Wenger, Etienne (2004)

Communities of Practice a Brief Introduction. Saatavilla www-muodossa <http://www.ewenger.com>. Viitattu 29.7.2005.

Yndigegn, Carsten \& Peter Waara \& Kari Paakkunainen (toim.) (2005)

Internet, Interaction and Networking: Post-National Identities of Youth in Cities around the Baltic Sea. Helsinki: Aleksanteri Papers 3, Finnish Youth Research Network/ Finnish Youth Research Society, Publications 58. 